INDEPENDENT JOURNAL OF MANAGEMENT \& PRODUCTION (IJM\&P)

\title{
THE NEED FOR A CHANGE IN THE PARADIGM OF ENTREPRENEURSHIP AT UNIVERSITIES: DIFFERENCES BETWEEN INNOVATIVE SPIN-OFFS AND TECHNOLOGY-BASED SPIN-OFFS
}

\author{
Enara Zarrabeitia \\ University of the Basque Country, Spain \\ E-mail: enara.zarrabeitia@ehu.eus \\ Patxi Ruiz de Arbulo \\ University of the Basque Country, Spain \\ E-mail: patxi.ruizdearbulo@ehu.eus \\ Pablo Diaz de Basurto \\ University of the Basque Country, Spain \\ E-mail: pablo.diazdebasurto@ehu.eus \\ Submission: 07/12/2015 \\ Revision: 13/01/2016 \\ Accept: 15/01/2016
}

\section{ABSTRACT}

This study seeks to analyse the main characteristics of and barriers to the growth and development of innovative university spin-offs (which originate mainly from the fields of social science and law) and technology-based university spin-offs (which tend to originate from the experimental sciences, from technical studies and from health science). The idea is to examine whether there is a need to redirect university policies aimed in the field of entrepreneurship. The study is based on a sample of 40 university spin-offs originating from the University of the Basque Country (UPV/EHU). A questionnaire was sent to entrepreneurs identified with the aid of the persons in charge of the university programmes for creating businesses at the UPVIEHU. To determine the main differences between innovative and technology-based spin-offs, once the replies were received a bivariate or contingent analysis was applied to characterise the two types of businesses. The main barriers to growth and development encountered by the two types were then identified. 
The data analysed reveal significant differences between the two types of businesses, and a need for a change in the paradigm of university entrepreneurship.

Keywords: University spin-offs, innovative spin-offs, technology-based spin-offs, university entrepreneurship, University of the Basque Country

\section{INTRODUCTION}

The creating and developing of businesses in a region contributes to trade and thus constitutes a major source of wealth creation. Support for entrepreneurship is therefore an essential strategy that must be fostered by public administrations if they wish to boost economic development in their areas.

However, merely setting up businesses does not necessarily suffice to produce these positive effects. If there is really a desire to foster a sustainable economic development in a region it is necessary for the businesses created to be high in knowledge content. This will enable them to act efficiently in the marketplace and thus grow, create jobs, internationalise, etc. (SEGUÍ et al., 2013; FONG, 2009).

The current economic crisis and the make-up of the fabric of business in Spain mean that it is now more necessary than ever to encourage the creation of innovative and technology-based businesses. It is essential to help set up businesses with a high capability for growth that can also provide added value in transforming the economic system as a whole to introduce new activities, new production techniques and new forms of management and thus enrich the region's stock of technical and entrepreneurial qualifications. In short, promoting such firms reinforces all the elements that foster integration into the knowledge society (FONG, 2009; MARTÍNEZ; TADEO, 2006).

The term "knowledge society" is used to describe a society fuelled by its diversity and its capabilities (UNESCO, 2005), in which the basic economic resource is and always will be knowledge itself. Organisations must be ready to abandon knowledge that has become obsolete and learn to create new knowledge by continuously improving their operations, developing new applications and engaging in continuous innovation as an organised process (ÁLVAREZ, 2012; DRUCKER, 1993). 
Thus, in the knowledge society there are actors of various kinds, including governments, research organisations and universities, which interact with businesses to give rise to a constant learning process. The roles played by these actors are vital for the sustainable economic growth of regions (TRILLO; FERNÁNDEZ, 2013; FERNÁNDEZ et al., 2011).

It was not until the end of the 20th century that it became clear in Spain that the strength of the economy depended, among other factors, on the proper transfer to production settings of new knowledge generated at universities (FECYT, 2006). It is now taken as given that universities must undertake the task of fostering economic development in their home areas. Accordingly, they need to find commercial applications for the knowledge that they generate (CONDOM; VALLS, 2006).

This being so, universities are increasingly aware of the need to exploit research outcomes commercially. Patents and research contracts are the most common ways of transferring knowledge generated at universities to society as a whole (SIEGEL; WALDMAN; LINK, 2003), but the creation of spin-offs has become increasingly popular at domestic and foreign universities in the past 10 years (MINISTERIO DE EDUCACIÓN Y CIENCIA, 2008; GÓMEZ et al., 2007). Many leading universities have even set up separate units to handle their interests in this field (BERAZA; RODRÍGUEZ, 2014).

Some Spanish universities have been commercially exploiting the knowledge that they generate through spin-offs for more than 15 years. Over that time a large number of widely differing spin-offs have been set up.

Two of the types of business set up are innovative spin-offs and technologybased spin-offs. The former originate mainly from the fields of social science and law, and the latter from the experimental sciences, technical studies and health science. Given the lack of empirical evidence in this area, this research study sets out to determine the main characteristics of and barriers to growth and development for both these types of spin-off, with a view to examining whether there is a need to redirect university policies in this field. 


\section{CHANGES OVER TIME IN THE FUNCTIONS OF UNIVERSITIES: THE SHIFT TOWARDS ENTREPRENEURIAL UNIVERSITIES}

Universities are among the oldest institutions in the western world. They have changed over time in line with the settings in which they have operated (BERAZA; RODRÍGUEZ, 2007).

The main mission of universities was conventionally seen as the provision of education and research, but this view gradually changed as new ideas concerning the role of universities within the system of production and valorisation of knowledge arose. The role of universities in economic development and their impact on society have become increasingly prominent, due to their own internal development and to external influences on academic structures (GÓMEZ et al., 2007). Nowadays they are seen as tasked with developing pure and applied scientific knowledge, passing that knowledge on through education, publication and dissemination and transferring it to organisations in their area of influence (businesses, public bodies, social organisations, etc.) to drive innovation and foster economic and social development there (BERAZA; RODRÍGUEZ, 2007).

An analysis of the different functions taken on by universities over the course of history reveals that there have been two "academic revolutions" which have changed the course that they have steered.

The first revolution took place in the late 19th and early 20th centuries, when the traditional role of universities in preserving and disseminating knowledge was extended by incorporating research (which had previously been undertaken separately at scientific societies and colleges) as a legitimate function for them. Universities thus took on the twin tasks of teaching and research and from then on their basic mission was to develop pure but empirically-based scientific knowledge and pass it on through education and publication. The introduction of research as an academic mission was not without controversy, as universities were generally seen as educational institutions whose sole purpose was to preserve and disseminate knowledge (BERAZA; RODRÍGUEZ, 2007; ETZKOWITZ, 2004).

Universities are currently undergoing a second academic revolution, the seeds of which can be seen as contained in the first, given that the conducting of research generated knowledge that could be marketed and capitalised. The first revolution, at 
DOI: 10.14807/ijmp.v7i2.410

the end of the 19th century, saw the incorporation of research alongside teaching, and the second, at the end of the 20th century, has entailed a further extension of the university remit to include establishing relations with business so as to foster economic and social development in their areas, thus giving rise to the concept of the "entrepreneurial university" (ETZKOWITZ, 2004; CONDOM; VALLS, 2003).

The shift from teaching universities to research universities and then to entrepreneurial universities can be attributed to a combination of various internal and external causes. Each step along the way can, to some extent, be seen as preparing the way for the next step. The desire to preserve and spread classical knowledge led to a desire to recover lost texts, thus sparking a process of research. Similarly, when scientific research was incorporated into universities its outcomes sometimes had unlooked-for potential practical applications (ETZKOWITZ, 2003). Finally, a number of organisational innovations in teaching and research established the foundations for entrepreneurial universities as they are now known (ETZKOWITZ, 2004).

\section{UNIVERSITY SPIN-OFFS AS A VEHICLE FOR TECHNOLOGY TRANSFER}

Currently, there is not sufficient consensus for a single model of analysis to be established that can determine precisely what activities are included in the so-called "third mission" of universities. However there is widespread agreement that actions for the transfer of knowledge and technology to the production system predominate over other activities that may potentially form part of the cooperation between universities and society (BUENO; CASANI, 2007).

Accordingly, although there are many different channels for the transfer of knowledge and technology between universities and businesses (indeed, any medium that enables a business to access specific knowledge or to make use of or market technology originating from universities can be classed as such), three main strategies are involved: projects carried out under contract, patent licensing and the creation of university spin-offs (ALBERT, 2008; GONZÁLEZ; ÁLVAREZ, 2005; CONDOM; VALLS, 2003).

The creation of spin-offs, in particular, has increased substantially in the past 10 years at universities in Spain and elsewhere (MINISTERIO DE EDUCACIÓN Y CIENCIA, 2008; GÓMEZ et al., 2007), because of their importance as a positive factor for regional socio-economic development (RODEIRO, 2008; MCDONALD et al. 
DOI: 10.14807/ijmp.v7i2.410

2004; MIAN, 1997). They are businesses that boost local economic development and growth, generate financial revenues for universities, enable technologies developed there to be marketed, increase interaction between universities and their surrounding areas, redirect teaching and research activities and spark changes in the culture of universities (RODEIRO; FERNÁNDEZ; VIVEL, 2011; SHANE, 2004).

The increasing numbers and repercussions of such businesses in high valueadded sectors of the economy can be attributed to two main factors: on the one hand they enable socio-economic returns to be obtained from university research through the dissemination and use of research outcomes by society; and on the other hand they generate profits (COSTAS; OURO, 2011).

\section{THE CONCEPT OF UNIVERSITY SPIN-OFFS}

Although they are becoming increasingly important, both to universities themselves and in terms of their contribution to the fabric of business (MORALES, 2008), there is no consensus in the relevant literature as to what exactly a "university spin-off' is. There is no consistency in the definitions and terms used in studies of university spin-offs, which is clearly a hindrance in obtaining an in-depth understanding of the associated phenomena and comparing the results of different research studies (BERAZA, 2010b; IGLESIAS, 2010).

The preparation of policies, strategies, programmes, etc. to foster, develop and consolidate new, innovative businesses originating from universities and future research on the matter are hampered by the widespread confusion in the specialist literature concerning the terms "innovative businesses", "technology-based businesses", "new technology-based businesses", "innovative technology-based businesses", "start-ups", "spin-outs" and "spin-offs". An attempt is made below to clarify and sort out these terms.

Beginning with the most general term according to the Central Directory of Businesses (DIRCE) of Spain's National Institute of Statistics (INE), innovative businesses can be defined as follows (INE, 2012):

- Innovative business: a business which in the past three years has introduced technologically new or improved products into the market, or technologically new or improved processes in its methods of production of goods or provision of services. 
Technology-based businesses, new technology-based businesses or innovative technology-based businesses are considered as a subgroup of innovative businesses. In this case there is no single definition of the concept in the relevant literature, but the following definition by the Office of Technology Assessment (1992) is widely accepted by the scientific community (MERINO; VILLAR, 2007):

- Technology-based business: a producer of goods and services committed to designing, developing and producing new products and/or innovative manufacturing processes via the systematic application of technical and scientific knowledge.

Thus, it can be seen that all technology-based businesses are innovative, but not all innovative businesses are necessarily technology-based (MERINO; VILLAR, 2007).

Some but not all "start-ups", "spin-outs" and "spin-offs" can be considered as a subgroup of innovative and technology-based businesses, though there is a great deal of confusion concerning these terms in the literature.

Beraza (2010b) \& Pirnay (2001) conclude that the concept of "spin-off" is difficult to pin down, and that although various authors have tried to define it their definitions do not entirely match. However, based on the definition given by Pirnay (2001), which is broadly cited in the relevant literature, a "spin-off" can be defined as follows:

- Spin-off: business generated from an existing organisation, which involves one or more individuals from the original organisation.

Depending on the nature of the original organisation, such businesses may be described as corporate spin-offs, institutional spin-offs or, as in the case studied here, university spin-offs (COTEC, 2003; LINDHOLM, 1997).

In a university context, "start-ups", "spin-outs" and "spin-offs" can be taken as equivalent, as any nuances of meaning between them are not significant. That said, entrepreneurs at some businesses of this type dislike the terms "spin-off" and "spinout", which they believe emphasise dependence on the parent organisation and fail to acknowledge the sacrifices in the form of money, time and effort normally required to set up a new company. The term "start-up" can be used in a broader sense for 
DOI: 10.14807/ijmp.v7i2.410

new firms not based on prior experience at other organisations (CONDOM; VALLS, 2003; STEFFENSEN; ROGERS; SPEAKMAN, 2000; CARAYANNIS et al., 1998).

Moreover, the evidence shows that European universities tend to use the term "spin-off" while those in the United States favour the term "start-up" (BERAZA, 2010b; CONDOM; VALLS, 2003).

In this study we use "spin-off", which is the term most widely used in the literature internationally and particularly in Spain. However even here there is no unanimity as to the definition and delimitation of "university spin-offs", and the term is often used differently by different authors.

In other words the term "university spin-off" has no single agreed meaning, but can be used to represent different things. However, most of the definitions given have two elements in common: on the one hand at least one of the entrepreneurs who create the spin-off must belong or have at some time belonged to the university community; and on the other hand the activities of the business must be based on knowledge that results from academic work. More specifically, the economic activity of the business must initially take place under the auspices of a university programme for the creation of businesses. The businesses created must be based on the commercial exploitation of knowledge generated at a university and must also be innovative or technology-based.

- University spin-off: an innovative or technology-based business set up under the auspices of a university programme for the commercial exploitation of knowledge generated at the university.

Figure 1 outlines the relationship between "innovative businesses", "technology-based businesses", "spin-offs" and "university spin-offs". 


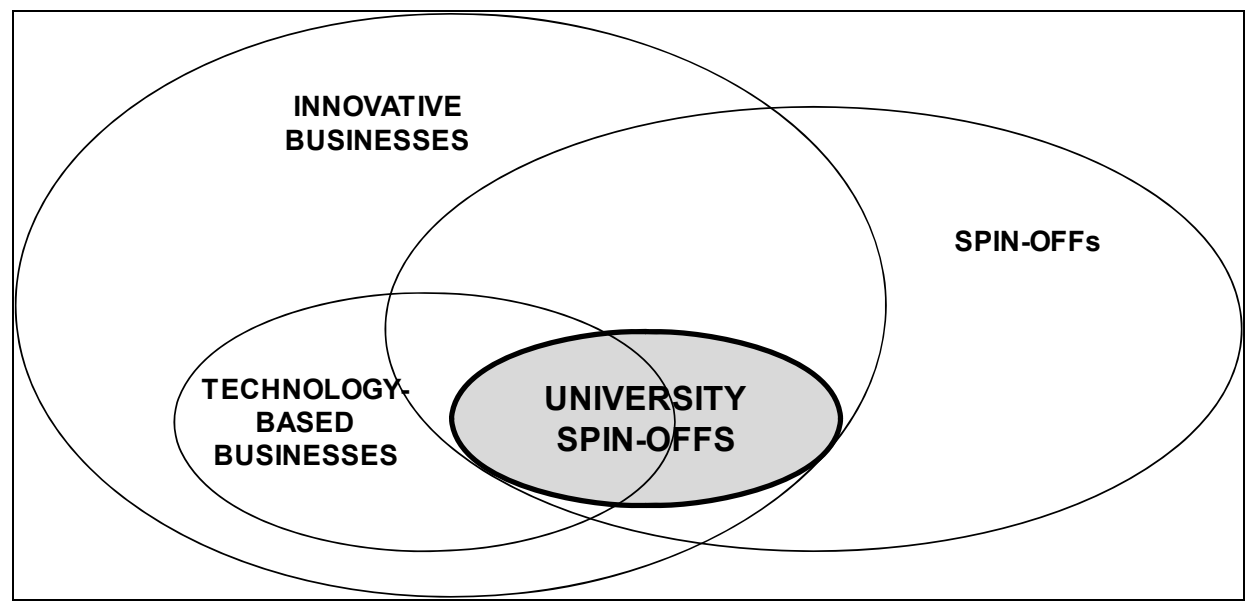

Figure 1: University spin-offs as a subgroup of innovative businesses and technology-based businesses.

\subsection{Innovative and technology-based spin-offs}

As indicated above, university spin-offs are heterogeneous businesses whose extent may vary significantly depending on how they are perceived by those involved on the ground and by the authors who write about them (BERAZA, 2010b).

The generally accepted definition of university spin-offs sets out the essential requirements that must be met for businesses to be considered as such. However the definition also covers a large variety of subgroups of university spin-offs, including innovative spin-offs and technology-based spin-offs.

They are all businesses based on knowledge generated at universities, but the extent of R\&D\&i (Research, Development and Innovation) at each differs. This means that the needs for their creation, development and consolidation are also different.

Innovative spin-offs originate generally from the fields of social science and law, while technology-based spin-offs tend to come from the experimental sciences, technical studies and health science. There is a need to encourage and help them all if knowledge generated from all knowledge areas at universities is to be properly commercially exploited.

\section{UNIVERSITY SPIN-OFFS IN SPAIN}

Legislation is an important factor in facilitating or hindering the development of entrepreneurial processes originating at universities. In Spain technological innovation, the transfer of knowledge and, specifically, the setting up of businesses by universities are governed by a range of different regulations (BERAZA, 2010a; 
MINISTERIO DE EDUCACIÓN Y CIENCIA, 2008). This section seeks to analyse the legal framework governing university spin-offs in Spain. An overview of the main characteristics of the spin-offs set up by various Spanish universities is then given to provide further understanding of the context in which businesses of this type operate.

\subsection{Spanish legislation concerning university spin-offs}

The first piece of legislation in Spain regulating technology-based businesses intended to disseminate and exploit the outcomes of research generated at universities was Public General Act [Ley Orgánica] 6/2001 (the Universities Act), which was subsequently amended by Public General Act [Ley Orgánica] 4/2007. Under these acts, such businesses are defined as businesses created or developed on the basis of patents for results arising from research projects funded wholly or partly from the public purse and carried out at universities.

More recently, Act 2/2011 of 4 March (the Sustainable Economy Act) established the possibility of universities fostering the creation of "innovative technology-based businesses", i.e. businesses in which one or more researchers can hold capital stakes with a view to exploiting for financial gain the results of their research and development work.

Act 11/2011 (the Science, Technology and Innovation Act) regulates the framework for the provision of services at trading companies, and establishes a category of business known as "young, innovative businesses". Under this act, such businesses are defined as those created less than six years previously whose spending on technological R\&D\&i amounts to at least $15 \%$ of their total spending in the past two years (or in the previous year in the case of firms less than two years old) which are confirmed to be developing products, services or processes which are technologically innovative or substantially better than the current state of the art in the relevant sector, and which entail technological or industrial risks.

But although Spanish legislation establishes certain requirements that university spin-offs must meet, it does not lay down a single, specific, overall definition of such businesses. Moreover, the terms most frequently used in the legislation are "technology-based business", "innovative technology-based business" and "young, innovative business", i.e. the English term "spin-off" (or its variants) widely used in the relevant literature does not appear. Moreover, although the 
legislation speaks of "young, innovative businesses" technology is clearly present in the definitions of all the terms used. This may actually be a hindrance for setting up firms based on the fields of social science and law.

Finally, it is worth noting that Spanish legislation on university spin-offs is supplemented by regulations drawn up by universities themselves.

\subsection{Characteristics of Spanish university spin-offs}

According to studies by Spain's Offices for the Transfer of Research Results (OTRI), by 2011 publicly-run universities in Spain had created approximately 1100 spin-offs (REDOTRI, 2011; REDOTRI, 2006), and their numbers followed an upward trend over the years (see Figure 2).

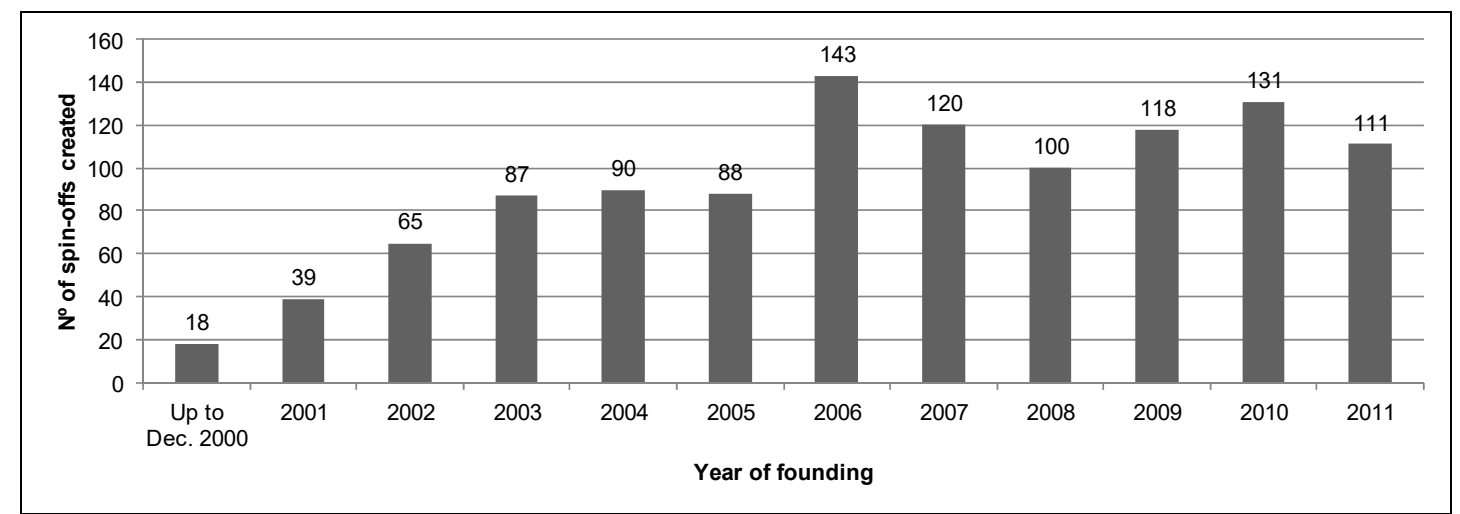

Figure 2: Changes over time in the creation of spin-offs at Spanish universities (2000-2011)

Source: Redotri, 2012; Redotri 2006

The links between university spin-offs and the universities that have created them reveal that creating spin-offs is an established practice. Table 1 shows the increasing trends in the number of spin-offs partly owned by universities, the returns or increases in value obtained by those spin-offs and the number of spin-offs that have increased their capital in recent years. However, these businesses need to mature further and overcome the incongruities that can still be observed in parameters such as the decrease in the number of researchers promoting spin-offs and the small percentage of spin-offs that have received technology from universities under licence in recent years (see Table 1). 
DOI: 10.14807/ijmp.v7i2.410

Table 1: Links between university spin-offs and the universities from which they came

\begin{tabular}{|c|c|c|c|c|c|}
\hline Year & $\begin{array}{c}\text { Spin-offs partly } \\
\text { owned by } \\
\text { universities }\end{array}$ & $\begin{array}{c}\text { Return from spin- } \\
\text { off in terms of } \\
\text { profit/increased } \\
\text { value (in } € \text { ) }\end{array}$ & $\begin{array}{c}\text { Research staff } \\
\text { promoting spin- } \\
\text { offs }\end{array}$ & $\begin{array}{c}\text { Spin-off under } \\
\text { university } \\
\text { technology licence }\end{array}$ & $\begin{array}{c}\text { Partly-owned spin- } \\
\text { offs that have } \\
\text { increased their } \\
\text { capital }\end{array}$ \\
\hline 2006 & 44 & 416000 & 215 & 37 & 13 \\
\hline 2007 & 14 & 0 & 197 & 46 & 21 \\
\hline 2008 & 22 & 0 & 185 & 27 & 10 \\
\hline 2009 & 37 & 31815 & 350 & 52 & 33 \\
\hline 2010 & 29 & 35560 & 259 & 55 & 37 \\
\hline 2011 & 37 & 76350 & 201 & 42 & 36 \\
\hline
\end{tabular}

Source: Redotri, 2012; Redotri, 2011

Finally, a study conducted by Ortín et al (2007) indicates that the sector of activity where most university spin-offs work is IT (hardware \& software) with $54 \%$, followed by R\&D (20\%), the chemical industry (17\%) and biotechnology (9\%). On the one hand this shows that the distribution of Spanish university spin-offs by sectors is similar to that observed in the USA, where $70 \%$ of new technology-based businesses founded between 1986 and 1999 belonged to the IT sector (GOMPERS, 2005). On the other hand, the absence of firms working directly in the fields of social science and law is noteworthy. So although there are innovative university spin-offs that originate from various knowledge areas in social science and law, they are all classed as operating in areas of activity related to the experimental sciences, technical studies and health science. This makes it difficult to study the different types of university spin-offs.

\section{RESEARCH METHODOLOGY}

The study carried out here is exploratory in that it seeks to provide knowledge on the actual situation of innovative and technology-based university spin-offs and consequently on the current paradigm of university entrepreneurship.

The primary information used concerns spin-offs created at the University of the Basque Country (UPV/EHU). The UPV/EHU exists as such since 1980, so it is a young university. However it has been in existence for more than 30 years, and was founded on the basis of a tradition and history that date back much further. Its first programme for creating businesses, and indeed its first spin-offs, appeared in 1997. It now has business creation programmes on all three of its campuses (Emprendedores Zitek in Bizkaia, Entreprenari in Gipuzkoa and Inizia Araba Campus in Araba), and has so far created 120 spin-offs (UPV/EHU, 2015). 
Our study covers the 91 university spin-offs created at the UPV/EHU up to October 2012. However, the results can largely be extrapolated to other relatively young universities which are active in all knowledge areas and have a consolidated track record of creating innovative and technology-based spin-offs.

We sent a questionnaire to entrepreneurs identified with the aid of those responsible for business creation programmes at the UPV/EHU. In other words, we identified researchers who had decided to create spin-offs originating from the UPV/EHU and who were still linked to the businesses created (i.e. the spin-offs were still operating and had not been sold). In the case of spin-offs with more than one entrepreneur, we selected the one who discovered, evaluated and decided to exploit the business opportunity, i.e. the researcher most closely involved in the whole process from the initial idea stage through to the setting up and development of the spin-off.

We received a total of 40 valid responses, which works out to a response rate of $44 \%$.

To determine the main differences between innovative and technology-based spin-offs, once the replies were received a bivariate or contingent analysis was applied to characterise the two types of businesses. The main barriers to growth and development encountered by the two types were then identified.

\section{RESULTS}

The results of our research are shown below. We begin by listing the main characteristics of the innovative and technology-based university spin-offs considered, and then examine the main barriers to growth and development encountered by both types of business.

\subsection{Main characteristics of innovative and technology-based university spin- offs}

Table 2 shows the main characteristics of innovative and technology-based university spin-offs.

It can be seen that $45 \%$ of the UPV/EHU spin-offs analysed are innovative, and $55 \%$ are not only innovative but also technology-based. In other words R\&D\&i is the core business of more than half of the spin-offs created, and not just a budget 
item. The data obtained also reveal a clear difference between innovative and technology-based businesses.

All the spin-offs examined focus on high and medium-level technology sectors and on knowledge-intensive sectors (EUROSTAT, 2011). However, the innovative spin-offs operate mainly in the service sector while the technology-based spin-offs focus on ICTs and on the medical/pharmaceutical/chemical sector.

The technology-based spin-offs achieve better results in practically all the characteristics analysed: they have bigger workforces on average, more holders of doctorates, more entrepreneurs per business, more female entrepreneurs per business, entrepreneurs with more experience in creating and developing spin-offs, bigger turnovers, higher rates of access to public and private funding sources and a higher proportion of firms which have registered industrial property rights (see Table 2).

Technology-based spin-offs are observed to have less difficulty in accessing a broader variety of funding sources, in spite of the risks inherent in the new technologies that they develop. Moreover, the low level of formal and informal venture capital investment observed in spin-offs reveals that their entrepreneurs are a highly committed to the projects that they have undertaken, though this could also be a sign of weakness in the financial system in regard to innovative and technologybased business initiatives (see Table 2).

Finally, in spite of the fact that the innovations and technologies developed by university spin-offs form the basis of their competitive edge, a shortfall can be observed in regard to ownership of industrial property rights, which prevent competitors from exploiting those same innovations and technologies. In general, innovative spin-offs are less able to absorb knowledge (see Table 2).

Specifically, Basque university spin-offs are observed to have little ability to absorb the knowledge that they generate through patents, which are the indicator most frequently employed in analysing innovation systems (BUESA; HEIJS; NAVARRO, 2007), in spite of the fact that patent rights could provide them with substantial income and could constitute a key asset for them (see Table 2). 
ISSN: 2236-269X

DOI: 10.14807/ijmp.v7i2.410

Table 2. Main characteristics of innovative \& technology-based university spin-offs

\begin{tabular}{|c|c|c|c|}
\hline & & \\
\hline & & INNOVATIVE SPIN-OFFS & TECHNOLOGY-BASED SPIN-OFFS \\
\hline Type of business & $\begin{array}{l}\text { Innovative or technology-based } \\
\text { business }\end{array}$ & $45 \%$ of spin-offs & $55 \%$ of spin-offs \\
\hline Sector of activity & Area of activity of the business & Services & $\begin{array}{l}\text { ICTs \& medicine, pharmaceuticals \& } \\
\text { chemicals }\end{array}$ \\
\hline \multirow{2}{*}{ Workforce } & $\mathrm{N}^{\circ}$ of employees & 3.87 employees/ spin-off & 6.68 employees/ spin-off \\
\hline & $\mathrm{N}^{\circ}$ of employees who hold doctorates & $10.3 \%$ of employees & $21.1 \%$ of employees \\
\hline \multirow{2}{*}{ Entrepreneurial team } & $\mathrm{N}^{\circ}$ of entrepreneurs & 3.17 entrepreneurs/ spin-off & 4.18 entrepreneurs/ spin-off \\
\hline & $\mathrm{N}^{\circ}$ of female entrepreneurs & $26.3 \%$ of entrepreneurs & $30.4 \%$ of entrepreneurs \\
\hline \multirow{3}{*}{$\begin{array}{l}\text { Experience of } \\
\text { entrepreneurs prior } \\
\text { creating the spin-off }\end{array}$} & Prior experience working in business & $88.9 \%$ of spin-offs & $86.4 \%$ of spin-offs \\
\hline & $\begin{array}{l}\text { Prior experience working in the } \\
\text { sector in which the spin-off operates }\end{array}$ & $55.6 \%$ of spin-offs & $68.2 \%$ of spin-offs \\
\hline & Experience in creating businesses & $44.4 \%$ of spin-offs & $45.5 \%$ of spin-offs \\
\hline \multirow{2}{*}{ Turnover \& profit } & Maximum turnover in the past year & $€ 250,000-€ 500,000$ & $>€ 1,000,000$ \\
\hline & Profit in the past year & $44.4 \%$ of businesses made a profit & $22.2 \%$ of businesses made a profit \\
\hline \multirow{5}{*}{$\begin{array}{l}\text { Sources of funding } \\
\text { used }\end{array}$} & Subsidies \& aid & $38.9 \%$ of spin-offs & $77.3 \%$ of spin-offs \\
\hline & Bank loans & $22.2 \%$ of spin-offs & $40.9 \%$ of spin-offs \\
\hline & Investment firms (venture capital) & $5.6 \%$ of spin-offs & $36.4 \%$ of spin-offs \\
\hline & Business angels & $0 \%$ of spin-offs & $9.1 \%$ of spin-offs \\
\hline & Loans from family, friends \& fools & $16.7 \%$ of spin-offs & $4.5 \%$ of spin-offs \\
\hline \multirow{4}{*}{ Industrial property } & Owner of patents & $16.7 \%$ of spin-offs & $31.8 \%$ of spin-offs \\
\hline & Owner of utility models & $5.6 \%$ of spin-offs & $13.6 \%$ of spin-offs \\
\hline & Owner of industrial designs & $5.6 \%$ of spin-offs & $4.5 \%$ of spin-offs \\
\hline & Owner of registered trade marks & $38.9 \%$ of spin-offs & $45.5 \%$ of spin-offs \\
\hline
\end{tabular}

Source: Own work

\subsection{Main barriers to growth and development of innovative and technology- based university spin-offs}

This section analyses the main barriers faced by innovative and technologybased university spin-offs as regards growth and development. Spin-offs were asked to rate the main barriers that they encountered using a five-point Likert scale (from "of no importance" to "highly important").

Their responses reveal that they believe their main problems to be a lack of financial resources, the innovative nature of their products/services, a lack of business experience and a lack of external contacts. All these factors were rated higher than average on the scale (see Figure 3).

Therefore, if the spin-offs originating from the University of the Basque Country are to consolidate themselves and attain high rates of growth the mechanisms designed to support them should focus on narrowing the gap between the need for capital at spin-offs and the willingness of the various actors who make up the Basque financial system to invest in them. They should also seek to help to orient the market towards the innovative products and services created by these 
DOI: 10.14807/ijmp.v7i2.410

businesses are improving their management as companies; and to help set up a network of contacts that can link Basque university spin-offs with potential investors, companies specialising in business management, suppliers, customers and other businesses.

The barriers in which there is most difference between the different types of spin-off are the difficulty encountered in internationalising and the high level of risk that their projects entail. In these two areas technology-based spin-offs experience difficulties 1.43 and 1.30 points higher, respectively, than those encountered by innovative spin-offs. On the other hand, innovative spin-offs rate the lack of qualified personnel and the innovative nature of products/services 0.49 and 0.38 points higher, respectively, on the scale of difficulties than technology-based spin-offs.

It is also noteworthy that it is mainly technology-based businesses that encounter barriers to growth and development (see Figure 3). Such R\&D\&i-intensive businesses can grow into major firms capable of helping create wealth in their home territories, but the risk inherent in the products that they develop means that they face barriers that hinder their development in their areas of operation. 


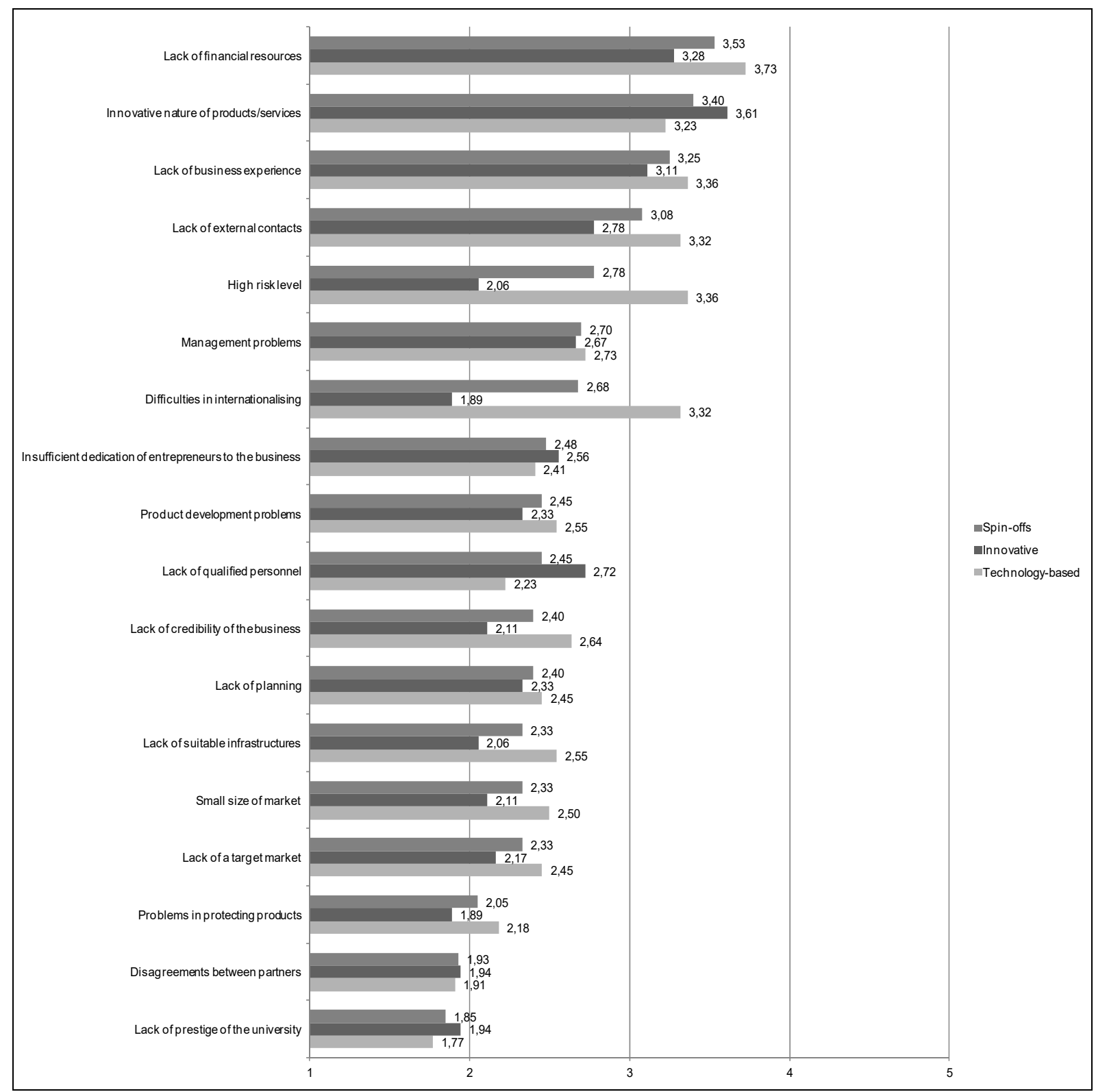

Figure 3: Main barriers to growth \& development of innovative \& technology-based university spin-offs.

Source: Own work

\section{CONCLUSIONS}

University spin-offs are playing an increasingly significant role in the sustainable development of regions. They not only provide an efficient way of transferring technology and research results from universities to society as a whole but also help to renovate the fabric of production in their home areas and to hold on to intellectual capital originating from universities.

In Spain the first university business creation programmes and the first university spin-offs date from before the turn of the 21st century. Over the years the 
number of businesses created has gradually grown, and their results have followed a largely positive trend. This is evidence that the practice has become consolidated and is approaching maturity.

However, the trend in this area and the changes that have taken place in the surrounding context on the one hand, and the appearance of different types of spinoff - each with its own particular features and specific needs - on the other mean that there is a need to redirect the unified university policies in regard to spin-offs applied to date at most Spanish universities.

This study confirms that there are two clearly distinct types of university spinoff, in practically equal proportions - innovative spin-offs and technology-based spinoffs - which apply technical and scientific knowledge to different extents in their business operations and which differ in terms of the results that they obtain, their needs and the barriers to creation, development and consolidation that they face.

Technology-based university spin-offs achieve better results than their innovative counterparts in terms of workforce numbers, employee qualifications and turnover, among other items. However this does not mean that less effort should be devoted to creating and developing innovative spin-offs. In spite of their apparent initial fragility compared to technology-based businesses, innovative spin-offs are worthy of consideration as businesses at all times because they represent different areas of university knowledge -generally from social science and law- that would otherwise not be directly commercialised.

The differences between these two types of spin-off are not limited to their results. A lack of financial resources is the main barrier to the successful development of spin-offs, and with this in mind it is worth stressing that innovative spin-offs find it more difficult to access different sources of public and private funding. In spite of the risks inherent in the new technologies developed by technology-based spin-offs, the fact that R\&D\&i is the core of their business and not just a budget item makes it easier for them to obtain funding.

However, technology-based spin-offs encounter more difficulties in growing and developing successfully. Although they may contribute high added value, they are businesses that will continue to need help even after some years in the marketplace. 
DOI: 10.14807/ijmp.v7i2.410

Legislation is an important aspect in facilitating or hindering the development of entrepreneurial processes originating from universities. In Spain the creation of businesses in a university setting is subject to a broad framework of regulations that establish certain requirements that such businesses must meet, but does not draw any distinction between innovative and technology-based spin-offs. This is an essential point that the relevant authorities need to take into account.

In view of the foregoing, a change in the paradigm of university entrepreneurship is considered necessary. Indeed, if the context into which such entrepreneurship is set changes and the type and nature of the businesses created evolve then the paradigm of university entrepreneurship itself should also change accordingly. One fundamental action that could be taken to adapt to the new situation is to distinguish between innovative and technology-based university spin-offs. Only then can the proper fit be achieved between actions by the actors that make up the ecosystem of Spanish entrepreneurship aimed at university spin-offs and the actual needs of the spin-offs themselves. Ultimately, the idea should be for this entrepreneurial activity to make as big a contribution as possible to sustainable social and economic development at regional level, through high-value-added activity sectors.

\section{REFERENCES}

ALBERT, A. (2008) Procesos de transferencia de conocimientos en el ámbito de la biotecnología. Arbor: Ciencia, Pensamiento y Cultura, n. 732, p. 677-686.

ÁLVAREZ, I. (2012) La gestión del conocimiento en la pyme: Análisis de la situación actual de la gestión del conocimiento en las pymes del País Vasco. Tesis Doctoral, Universidad del País Vasco.

BERAZA, J. M. (2010a) La creación de spin-offs universitarias en la universidad española: marco legal. Revista de Dirección y Administración de Empresas, $n$. 17, p. 73-98.

BERAZA, J. M. (2010b) Los programas de apoyo a la creación de spin-offs académicas en las universidades españolas: una comparación internacional. Tesis Doctoral, Universidad del País Vasco.

BERAZA, J. M.; RODRÍGUEZ, A. (2007) La evolución de la misión de la universidad. Revista de Dirección y Administración de Empresas, n. 14, p. 25-56.

BERAZA, J. M.; RODRÍGUEZ, A. (2014) Diseño de programas de apoyo a la creación de spin-off académica. Revista de Dirección y Administración de Empresas, n. 21, p. 119-140. 
BUENO, E.; CASANI, F. (2007) La tercera misión de la universidad. Enfoques e indicadores básicos para su evaluación. Economía Industrial, n. 366, p. 43-59.

BUESA, M.; HEIJS, J.; NAVARRO, M. (2007) Medición de la innovación. Indicadores regionales. En Buesa, M., Heijs, J. (coord.), Sistemas regionales de innovación: nuevas formas de análisis y medición, Funcas, Madrid, p. 91-142.

CARAYANNIS, E.; ROGERS, E. M.; KURIHARA, K.; ALLBRITTON, M. M. (1998). High-Technology spin-offs from government R\&D laboratories and research universities. Technovation, v. 18, n. 1, p. 1-11.

CONDOM, P.; VALLS, J. (2003) La creación de empresas desde la universidad: las spin-offs. Iniciativa Emprendedora y Empresa Familiar, n. 38, p. 46-64.

CONDOM, P.; VALLS, J. (2006) La creación de empresas spin-off en las universidades emprendedoras. Alta Dirección, n. 241-242, p. 192-202.

COSTAS, I.; OURO, A. (2011) Participación de los investigadores en los resultados de la investigación. El entorno legal: proyectos de Ley de la Ciencia, la Tecnología y la Innovación y de la Ley de Economía Sostenible. Diario La Ley, p. 7615.

COTEC (2003) Nuevos mecanismos de transferencia de tecnología. Debilidades y oportunidades del Sistema Español de Transferencia de Tecnología. Encuentros Empresariales Cotec 9. Fundación Cotec para la Innovación Tecnológica, Madrid.

DRUCKER, P. (1993) La sociedad poscapitalista. Apóstrofe, Barcelona.

ETZKOWITZ, H. (2003) El auge de la universidad emprendedora. Iniciativa Emprendedora y Empresa Familiar, n. 41, p. 13-33.

ETZKOWITZ, H. (2004) The evolution of the entrepreneurial university. International Journal of Technology and Globalisation, v. 1, n. 1, p. 64-77.

EUROSTAT (2011) High technology and knowledge-intensive sectors. Eurostat.

FECYT (2006) Carencias y necesidades del sistema español de ciencia y tecnología. Recomendaciones para mejorar los procesos de transferencia de conocimiento y tecnología a las empresas. Informe 2005. Available:

http://icono.fecyt.es/informesypublicaciones/Documents/carencias.pdf. Access: May 27, 2015.

FERNÁNDEZ, M.; MERCHÁN, C.; RODRÍGUEZ, L.; BALMACEDA O. (2011) Indicadores de transferencia de conocimiento: una propuesta de medida de la cooperación entre universidad y empresa. Documento de trabajo, Instituto de Estudios Sociales Avanzados (IESA), CSIC, Córdoba.

FONG, C. (2009) Patrones de creación de empresa competitiva en la coyuntura actual: El caso de las empresas de tipo spin-off de origen universitario.

Administrando En Entornos Inciertos, Managing in Uncertain Environment, $p$. 142.

GÓMEZ, J. M.; MIRA, I.; VERDÚ, A. J.; SANCHO, J. (2007) Las spin-offs académicas como vía de transferencia tecnológica. Economía Industrial, n. 366, p. 61-72. 
GOMPERS, P.; LERNER, J.; SCHARFSTEIN, D. (2005) Enterpreneurial Spawning: Public Corporations and the genesis of New Ventures, 1986 to 1999. The Journal of Finance, p. 577-614.

GONZÁLEZ, O.; ÁLVAREZ, J. A. (2005) Las spin off en la estrategia de transferencia de conocimientos de las universidades españolas, XIV Jornadas de la Asociación de Economía de la Educación, Oviedo, p. 1-12.

IGLESIAS, P. P. (2010) Las Spin-Off Universitarias como mecanismo de transferencia de tecnología y su impacto económico en base a la actividad de I+D+i. Tesis Doctoral, Universidad de Málaga.

INE (2012) Encuesta sobre Innovación Tecnológica en las Empresas. Instituto Nacional de Estadística. Available:

http://www.ine.es/dynt3/metadatos/es/RespuestaDatos.htm?oe=30061. Access: June 3, 2015.

LEY 2/2011, de 4 de marzo, de Economía Sostenible; publicada en BOE $n^{\circ} 55$ de 5 de marzo de 2011.

LEY 14/2011, de 1 de junio, de la Ciencia, la Tecnología y la Innovación; publicada en BOE $n^{\circ} 131$ de 2 de junio de 2011.

LEY ORGÁNICA 4/2007, de 12 de abril, por la que se modifica la Ley Orgánica 6/2001, de Universidades; publicada en BOE nº 89 de 13 de abril de 2007.

LEY ORGÁNICA 6/2001, de 21 de diciembre, de Universidades; publicada en BOE n 307 de 21 de diciembre de 2001.

LINDHOLM, A (1997) Entrepreneurial Spin-off Enterprises in Göteborg, Sweden. European Planning Studies, v. 5, n. 5, p. 661-675.

MCDONALD, L.; CAPART, G.; BOHLANDER, B.; CORDONNIER, M.; JONSSON, L.; KAISER, L.; LACK, J.; MACK, J.; MATACOTTA, C.; SCHWING, T.; SUEUR, T.; VAN GREVENSTEIN, P.; VAN DEN BOS, L.; VONORTAS, N. (2004) Management of intellectual property in publicly-funded research organisations: Towards European Guidelines. Office for Official Publications of the European Communities, Luxembourg.

MERINO, C.; VILLAR, L. (2007) Factores de éxito en los procesos de creación de empresas de base tecnológica. Economía Industrial, n. 366, p. 147-167.

MIAN, S. A. (1997) Assessing and managing the university technology business incubator: an integrative framework. Journal of Business Venturing, v. 12, n. 5, p. 251-285.

MINISTERIO DE EDUCACIÓN Y CIENCIA (2008) La creación de empresas de base tecnológica en el ámbito universitario a partir de la reforma de la LOU. Ministerio de Educación y Ciencia, Madrid.

MORALES, S. T. (2008). El emprendedor académico y la decisión de crear spinoff: un análisis del caso español. Tesis Doctoral, Universidad de Valencia.

OFFICE Of TECHNOLOGY ASSESSMENT (1992) Building Future Security: Strategies for Restructuring the Defense Technology and Industrial Base. Congress of the United States. 
ORTÍN, P.; SALAS, V.; TRUJILLO, M. V.; VENDRELL, F. (2007) El spin-off universitario en España como modelo de creación de empresas intensivas en conocimiento. Ministerio de Industria, Turismo y Comercio. Secretaría General de Industria. DGPYME.

PIRNAY, F. (2001). La valorisation économique des résultats de recherche universitaire par création d'activités nouvelles (spin-offs universitaires): Propositions d'un cadre procédural d'essaimage. Thèse de doctorat ès Sciences de Gestion. Université du Droit et de la Santé - Lille 2, Lille.

REDOTRI (2006) Memoria RedOTRI 2006. RedOTRI Universidades y Crue, Madrid. Available: http://www.redotriuniversidades.net/index.php/memoria-redotri/5memorias-de-redotri/informe-redotri-2006/detail. Access: June 9, 2015.

REDOTRI (2011) Informe de la encuesta de investigación y transferencia de conocimiento 2010 en las universidades españolas. RedOTRI Universidades y Crue, Madrid. Available: http://www.redotriuniversidades.net/index.php/informaencuesta/6-encuesta-redotri/informe-encuesta-i-tc-2010/detail. Access: June 9, 2015.

REDOTRI (2012) Informe de la encuesta de investigación y transferencia de conocimiento 2011 en las universidades españolas. RedOTRI Universidades y Crue, Madrid. Available: http://www.redotriuniversidades.net/index.php/informaencuesta/6-encuesta-redotri/informe-encuesta-i-tc-2011/detail. Access: June 9, 2015.

RODEIRO, D. (2008) La creación de empresas en el entorno universitario español y la determinación de su estructura financiera. Tesis Doctoral, Universidad de Santiago de Compostela.

RODEIRO, D.; FERNÁNDEZ, S.; VIVEL, M. M. (2011) Universidad emprendedora. La creación de spin-offs, en FERNÁNDEZ, S., RODEIRO, D. (coords), EI emprendimiento femenino en el sistema universitario español y gallego. Un análisis económico-financiero, Universidad de Santiago de Compostela, p. 73122.

SEGUÍ, E.; SARRIÓN, F.; TORMO, G.; OLTRA, V. (2013) Estudio del emprendimiento académico bajo fórmulas de economía social: análisis de las spinoff universitarias cooperativas. Ciriec, n. 78, p. 101-124.

SHANE, S. (2004) Academic Entrepreneurship: University Spin-Offs and Wealth Creation. Edward Elgar, Cheltenham, UK.

SIEGEL, D. S.; WALDMAN, D. A; LINK, A. N. (2003) Assessing the impact of organizational practices on the relative productivity of university technology transfer offices: an exploratory study. Research Policy, v. 1, n. 32, p. 27-48.

STEFFENSEN, M.; ROGERS, E. M.; SPEAKMAN, K. (2000) Spin-offs from research centers at a research university. Journal of Business Venturing, v. 15, n. 1, p. 93111.

TRILLO, M. A.; FERNÁNDEZ, M. (2013) Caracterización de la innovación en spin-off de base tecnológica. Economía Industrial, n. 388, p. 67-78.

UNESCO (2005) Towards knowledge societies. Unesco Publishing, Paris.

UPV/EHU (2015) Programas de creación de empresas de la UPV/EHU. Universidad del País Vasco. Available: 
ISSN: 2236-269X

DOI: 10.14807/ijmp.v7i2.410

http://www.ehu.eus/es/web/enpresa/enpresak-sortzeko-programak. Access: June 10, 2015. 